\title{
EFFECT OF USING GARLIC POWDER AS NATURAL FEED ADDITIVE ON PERFORMANCE AND CARCASS QUALITY OF BROILER CHICKS
}

\author{
SAFA M.A. ELTAZI; MOHAMED, K.A. ${ }^{* *}$ and MUKHTAR, M.A.* \\ *Safa Mohamed A/ELWahab Eltazi, Faculty of Agriculture, Omdurman Islamic University, P.O. Box 383, Sudan. \\ ${ }^{* *}$ College of Agricultural Studies, Sudan University of Science and Technology, Khartoum North, Shambat, P.O. Box 407. \\ E-Mail:safamohamedeltazi@yahoo.com.
}

\begin{tabular}{ll} 
ABSTRACT \\
\hline Received at: 23/3/2014 & $\begin{array}{l}\text { The effect of feeding broiler chicks on diets containing different levels of garlic } \\
\text { powder as natural feed additive on productive performance, carcass } \\
\text { characteristics and economical efficiency were studied. A total of one hundred }\end{array}$ \\
and sixty one-day old, unsexed (Habbard) broiler chicks were randomly divided \\
into four experimental groups. Each group was further subdivided into five \\
replicates eight chicks per pen in complete randomized design. The birds were \\
fed on two basal diets (starter and finisher). The garlic powder (Allium sativum) \\
was added to the basal diets at (0.0, 2.0, 3.0 and 4.0\%) levels resulting in four \\
formulae respectively to groups A, B, C and D with group A serving as control \\
group. The experimental diets were fed for 6 -weeks duration. Health of the \\
stock and performance parameters were recorded. At the end of the experiment, \\
the birds were slaughtered, dressed for estimating the different parameters \\
economical evaluation was also calculated. The results showed that, the diet \\
with $3 \%$ garlic powder had significantly (P $<0.05$ ) heaviest body weight gain, \\
highest feed intake, best feed conversion ratio with highest dressing and breast \\
percentages. The birds fed on control group produced significantly (P $<0.05$ ) \\
highest abdominal fat percentage. The mortality rate was not affected \\
significantly by the addition of garlic powder in broiler diet. The highest \\
profitability ratio $(1.30)$ was recorded by the diet with $3 \%$ garlic powder as \\
compared to other experimental diets.
\end{tabular}

Key words: Garlic powder, Feed additive, Carcass quality.

\section{INTRODUCTION}

The fast growing nature of broilers and their short generation intervals has been associated over the years with the use of antibiotic growth promoter at sub-therapeutic doses in animal feed, in order to improve performance through controlling the zoonotic pathogens in the gut (Dieumou et al., 2009). Although birds raised with these feed additive achieved good performance, their potential side effects became a real public health problem worldwide (Bager, 1998; Donoghue, 2003) and led to the ban of these products by the European Union in January 2006. This decision has therefore stimulated a search for alternatives. Recently medicinal herbs and their associated essential oils or extract are being concerned as potentially growth promoters. They consist of mixtures of compounds which have many effects as antimicrobial, stimulating animal digestive system, antioxidants, anticoccidial, increase production of digestive enzymes and improve utilization of digestive products by enhancing liver functions (Ziarlarimi et al., 2011). Garlic (Allium sativum) which is a perennial herb with a bulb divided into segments (cloves) (Singh and Panda, 2005) and belongs to the family Amaryllidaceae and genus Allium (Wikipedia, the free encyclopedia (2013), is widely used in all parts of world as a spice and herbal medicine for the prevention and treatment of a variety of diseases ranging from infection to heart diseases. Garlic has several beneficial effects on both humans and animal having antimicrobial, antioxidant properties (Konjufca et al., 1997); antiviral (Weber et al., 1992); and antifungal (Ankri and Mirelman, 1999). Garlic supplement to broiler chicks has been recognized for its strong stimulating effect on the immune system in addition to its positive effects on digestion in birds due to the very rich aromatic essential content of it (Demir et al., 2005). These functions were attributed to the bioactive compounds present in garlic such as alliin, daillyl sulphide and allicin (Amagase and Milner, 
1993), which possess antimicrobial activity (Tsao and Yin, 2001) that could be responsible for the growth promoting effect of garlic.

The objective of this study was intended to gain more information about the effect of using garlic powder as natural feed additive on performance and carcass quality of broiler chicks.

\section{MATERIALS and METHODS}

A total of 160 one-day old unsexed (Habbard) broiler chicks were randomly distributed into 4 groups of 40 chicks per group. Each group was further subdivided into 5 replicates with 8 chicks per each. The chicks of each replicate were housed in a pen (1 square meter) in an open-sided deep litter house. The garlic bulbs (Allium sativum) which were purchased from local market desegmented into cloves then cut into chips. The chips were sun dried, grounded to fine powder and then added to the basal diets at the levels $(0.0,2$, 3 and 4\%) resulting in four formulae respectively to group A, B, C and D with group A serving as control group. All the experimental diets were formulated to meet the nutrient requirements of broiler chicks according to NRC (1994) which was formulated from the local feed ingredients commonly used for poultry feeding in the Sudan. The experimental diets were fed for 6-weeks duration where two phases of feeding program involved in supplying starter (1-21 days of age) and finisher (22-42 days of age). Calculated analysis of the experimental basal diets was done according to feedstuff analysis outlined by Ellis (1981), while determined chemical analysis was conducted by the method of AOAC (1995). Ingredients, proximate analysis and calculated analysis for the experimental basal diets are shown in Tables (1 \& 2), respectively, while chemical composition of the super concentrate used in the basal diets is shown in Table (3). Feed and water were offered ad-libitum. The light was continuous throughout the experimental period. The performance of the experimental birds in term of feed intake, live weight gain and feed conversion ratio were recorded weekly. Health of the experimental stock and mortality rate were closely observed and recorded daily. At the end of $6^{\text {th }}$ week the experimental birds were individually weighed after overnight fast (except for water) then slaughtered without stunning. They were then scalded, manually plucked, washed and allowed to drain on wooden tables. Evisceration was performed by a ventral cut and visceral as well as thoracic organs were removed. After evisceration internal organs (heart, liver and gizzard) were removed, weighed individually and expressed as percentage of slaughtered weight. Eviscerated carcasses were weighed and then chilled in a refrigerator for 24 hours at $4^{\circ} \mathrm{C}$. Cold carcasses were recorded.

Table 1: Ingredients and proximate analysis of the experimental basal diets (percent as fed)

\begin{tabular}{llcc}
\hline & Item & $\begin{array}{c}\text { Starter } \\
(0-3 w e e k s)\end{array}$ & $\begin{array}{c}\text { Finisher } \\
(4-7 \text { weeks })\end{array}$ \\
\hline A: $\quad$ & & \\
\hline & Ingredients\%: & 65.00 \\
\hline Grain sorghum & 53.00 & 5.00 \\
\hline Wheat bran & 7.00 & 11.00 \\
\hline Groundnut meal & 12.00 & 9.00 \\
\hline Sesame meal & 18.00 & 5.00 \\
\hline Super concentrate & 5.00 & 2.75 \\
\hline Oyster shell & 2.75 & 0.25 \\
\hline Common salt & 0.25 & 2.00 \\
\hline Vegetable oil (corn) & 2.00 & 100 \\
\hline & Total & 100 & 95.00 \\
\hline B: & & 20.00 \\
\hline & Determined analysis, \% & 97.00 & 6.78 \\
\hline Dry matter & 23.28 & 5.40 \\
\hline Crude protein (N\% x 6.25) & 5.59 & 8.74 \\
\hline Ether extract & 6.46 & 54.06 \\
\hline Crude fibre & 10.49 & \\
\hline Ash & 51.18 & \\
\hline Nitrogen free-extract & & \\
\hline
\end{tabular}


Assiut Vet. Med. J. Vol. 60 No. 141 April 2014

Table 2: Calculated analysis of the experimental diets on dry matter basis (DM).

\begin{tabular}{lcc}
\hline \multicolumn{1}{c}{ Item } & $\begin{array}{c}\text { Starter } \\
(0-3 \text { weeks })\end{array}$ & $\begin{array}{c}\text { Finisher } \\
(4-7 \text { weeks })\end{array}$ \\
\hline Metabolizable energy $(\mathrm{Kcal} / \mathrm{kg})$ & 2940 & 3027 \\
\hline Crude fat, $\%$ & 7.91 & 6.57 \\
\hline Crude protein, $\%$ & 23.12 & 20.09 \\
\hline Lysine, $\%$ & 1.13 & 1.03 \\
\hline Methionine, $\%$ & 0.53 & 0.44 \\
\hline Cystine, $\%$ & 0.36 & 0.29 \\
\hline Methionine + cystine, $\%$ & 0.89 & 0.73 \\
\hline Calcium, $\%$ & 1.14 & 0.97 \\
\hline Available phosphorus, $\%$ & 0.73 & 151 \\
\hline Caloric-protein ratio & 127 & \\
\hline ME Kcal/kg: protein $\%$ & &
\end{tabular}

Metabolizable energy: calculated according to Ellis (1981)

Table 3: Chemical composition of the super concentrate used in the experimental diet formulation (Hendrix broiler concentrate)

\begin{tabular}{llc}
\hline Metabolizable energy & $1900(\mathrm{Kcal} / \mathrm{kg})$ \\
\hline Crude protein & & $32.00 \%$ \\
\hline & Lysine & $11.00 \%$ \\
\hline & Methionine & $2.80 \%$ \\
\hline Calcium & Methionine + cystine & $2.25 \%$ \\
\hline Available phosphorus & & $8.00 \%$ \\
\hline
\end{tabular}

All the slaughtered birds were used for dissection. The breast, thigh and drumstick of the left side of each carcass were dislocated, weighed and expressed as percentage of cold carcass weight. Taste panel was done for broiler's breast and thigh meat after wrapped individually in aluminum foil, and roasted in an electric oven at $175^{\circ} \mathrm{C}$ for 90 minutes. Ten taste panelists were used to score colour, flavour, tenderness and juiciness of the meat, according to the guidelines of Cross et al. (1978). Statistical analyses were made by analysis of variance for a completely randomized design, according to Steel and Torrie (1986)

\section{RESULTS}

The effect of feeding different levels of garlic powder on broiler's performance is shown in Table (4). Final body weight, body weight gain, total feed intake and feed conversion ratio were significantly $(\mathrm{P}<0.05)$ affected by different levels of garlic powder. Generally the inclusion of garlic powder in the experimental diets improved significantly $(\mathrm{P}<0.05)$ the broiler's performance. The diet with $3 \%$ level of garlic powder showed significantly $(\mathrm{P}<0.05)$ heaviest final body weight and body weight gain, highest total feed intake with the best feed conversion ratio as compared to the other experimental diets. The experimental treatments had no significant $(\mathrm{P}>0.05)$ effect on the mortality rate. Only one bird from each treatment was died, which cannot be related in any way to the experimental treatment. 
Assiut Vet. Med. J. Vol. 60 No. 141 April 2014

Table 4: The effect of feeding different levels of garlic powder on performance of broiler chicks (1-42 days).

\begin{tabular}{lccccc}
\hline \multicolumn{1}{c}{ Parameter } & A & B & C & D & SEM \\
\hline Initial live weight (g/chick) & 45.52 & 45.02 & 45.18 & 45.39 & - \\
\hline Final live weight (g/chick) & $1857.63^{\mathrm{c}}$ & $2026.13^{\mathrm{b}}$ & $2145.19^{\mathrm{a}}$ & $1976.50^{\mathrm{b}}$ & 9.83 \\
\hline Body weigh gain (g/chick) & $1812.11^{\mathrm{c}}$ & $1981.11^{\mathrm{b}}$ & $2100.01^{\mathrm{a}}$ & $1931.10^{\mathrm{b}}$ & 9.72 \\
\hline Total feed intake (g/chick) & $3624.22^{\mathrm{c}}$ & $3843.35^{\mathrm{b}}$ & $4032.01^{\mathrm{a}}$ & $3784.95^{\mathrm{b}}$ & 9.77 \\
\hline Feed conversion ratio & $2.00^{\mathrm{a}}$ & $1.94^{\mathrm{b}}$ & $1.92^{\mathrm{c}}$ & $1.96^{\mathrm{b}}$ & 0.006 \\
\hline Mortality \% & 1.00 & 1.00 & 1.00 & 1.00 & $0.001^{\mathrm{NS}}$ \\
\hline
\end{tabular}

A: Control (without garlic powder)

B: $2 \%$ garlic powder

C: $3 \%$ garlic powder

D: $4 \%$ garlic powder

SEM: Standard error of the mean

N.S. Not statistically significant $(\mathrm{P}>0.05)$

Means on the same raw with the same superscripts are not significantly different $(\mathrm{P}>0.05)$.

Table (5) shows the effect of feeding different levels of garlic powder on carcass characteristic of the broilers. All the measured parameters were significantly $(\mathrm{P}<0.05)$ affected by the different levels of garlic powder. The inclusion of garlic powder in the broiler diets significantly $(\mathrm{P}<0.05)$ improved the hot and cold dressing percentages and breast percentage compared to the control diet. Birds fed on 3\% level of garlic powder gave significantly $(\mathrm{P}<0.05)$ highest hot and cold dressing percentages and highest breast percentage compared to other experimental groups. On the other hand, the highest percentages of the drumstick and thigh meat significantly $(\mathrm{P}<0.05)$ were recorded by the control group.

Table 5: Means values for the dressing carcass percentages and commercial cut of broiler carcasses.

\begin{tabular}{lccccc}
\hline \multicolumn{1}{c}{ Parameter } & A & B & C & D & SEM \\
\hline Hot dressing percentages & $68.82^{\mathrm{c}}$ & $69.01^{\mathrm{b}}$ & $70.02^{\mathrm{a}}$ & $68.99^{\mathrm{b}}$ & 0.15 \\
\hline Cold dressing percentage & $68.00^{\mathrm{c}}$ & $68.80^{\mathrm{b}}$ & $69.82^{\mathrm{a}}$ & $68.62^{\mathrm{b}}$ & 0.12 \\
\hline Breast as \% of cold carcass & $24.92^{\mathrm{c}}$ & $25.80^{\mathrm{b}}$ & $26.50^{\mathrm{a}}$ & $25.50^{\mathrm{b}}$ & 1.32 \\
\hline Drumstick as \% of cold carcass & $15.90^{\mathrm{a}}$ & $15.11^{\mathrm{b}}$ & $15.01^{\mathrm{b}}$ & $15.00^{\mathrm{b}}$ & 0.25 \\
\hline Thigh as \% of cold carcass & $16.80^{\mathrm{a}}$ & $15.20^{\mathrm{b}}$ & $15.02^{\mathrm{b}}$ & $15.00^{\mathrm{b}}$ & 0.24 \\
\hline
\end{tabular}

A: Control (without garlic powder)

B: $2 \%$ garlic powder

C: $3 \%$ garlic powder

D: $4 \%$ garlic powder

SEM: Standard error of the means

Means on the same raw with the same superscripts are not significantly different $(\mathrm{P}>0.05)$.

Table (6) shows the effect of feeding different levels of garlic powder on the giblets as the percentage of body weight. The dietary treatment significantly $(\mathrm{P}<0.05)$ influenced the development of organs of the broilers except the heart percentage. Generally, the inclusion of garlic powder in the diets lowering the percentages of these organs (abdominal fat, liver and gizzard). Birds fed the garlic powder diets produced significantly $(\mathrm{P}<0.05)$ the lowest percentage of abdominal fat, liver and gizzard, while those fed the control diet produced the highest percentages of these organs. 
$\underline{\text { Assiut Vet. Med. J. Vol. } 60 \text { No. } 141 \text { April } 2014}$

Table 6: Body weight and organ proportions of broiler chickens

\begin{tabular}{lccccc}
\hline \multicolumn{1}{c}{ Parameters } & $\mathrm{A}$ & $\mathrm{B}$ & $\mathrm{C}$ & $\mathrm{D}$ & SEM \\
\hline Final body weight (g/chick) & 1857.63 & 2026.13 & 2145.19 & 1976.50 & 9.83 \\
\hline Abdominal fat as \% of body weight & $2.20^{\mathrm{a}}$ & $1.93^{\mathrm{b}}$ & $1.92^{\mathrm{b}}$ & $1.90^{\mathrm{b}}$ & 0.015 \\
\hline Liver as \% of body weight & $2.25^{\mathrm{a}}$ & $2.16^{\mathrm{b}}$ & $2.10^{\mathrm{b}}$ & $2.01^{\mathrm{b}}$ & 0.02 \\
\hline Heart as \% of body weight & 0.53 & 0.55 & 0.56 & 0.53 & $0.012^{\mathrm{NS}}$ \\
\hline Gizzard as \% of body weight & $2.56^{\mathrm{a}}$ & $2.09^{\mathrm{b}}$ & $2.05^{\mathrm{b}}$ & $2.01^{\mathrm{b}}$ & 0.03 \\
\hline
\end{tabular}

A: Control (without garlic powder)

B: $2 \%$ garlic powder

C: $3 \%$ garlic powder

D: $4 \%$ garlic powder

SEM: Standard error of the means

NS: Not statistically significant $(\mathrm{P}>0.05)$

Means on the same raw with the same superscripts are not significantly different $(\mathrm{P}>0.05)$.

Table (7) shows the effect of dietary treatment on subjective scores for breast and thigh of broiler meat. The values of tenderness, juiciness, flavour and colour did not differ significantly $(\mathrm{P}>0.05)$ among the dietary treatments and the score given for all attributes are above moderate acceptability level.

Table 7: Subjective scores for the breast and thigh of broiler meat.

\begin{tabular}{|c|c|c|c|c|c|}
\hline Parameter & A & B & $\mathrm{C}$ & $\mathrm{D}$ & SEM \\
\hline \multicolumn{6}{|l|}{ Tenderness } \\
\hline Thigh & 5.62 & 5.35 & 5.48 & 5.22 & $0.04^{\mathrm{Ns}}$ \\
\hline Breast & 5.34 & 5.20 & 5.21 & 5.01 & $0.03^{\mathrm{NS}}$ \\
\hline \multicolumn{6}{|l|}{ Juiciness } \\
\hline Thigh & 5.52 & 5.70 & 5.55 & 5.46 & $0.03^{\mathrm{NS}}$ \\
\hline Breast & 5.43 & 5.61 & 5.43 & 5.31 & $0.02^{\mathrm{NS}}$ \\
\hline \multicolumn{6}{|l|}{ Flavour } \\
\hline Thigh & 5.51 & 5.36 & 5.29 & 5.58 & $0.03^{\mathrm{NS}}$ \\
\hline Breast & 5.62 & 5.75 & 5.60 & 5.42 & $0.03^{\mathrm{NS}}$ \\
\hline \multicolumn{6}{|l|}{ Colour } \\
\hline Thigh & 5.29 & 5.51 & 5.60 & 5.42 & $0.04^{\mathrm{NS}}$ \\
\hline Breast & 5.35 & 5.40 & 5.22 & 5.35 & $0.03^{\mathrm{NS}}$ \\
\hline
\end{tabular}

A: Control (without garlic powder)

B: $2 \%$ garlic powder

C: $3 \%$ garlic powder

D: $4 \%$ garlic powder

SEM: Standard error of the means

NS: Not statistically significant $(\mathrm{P}>0.05)$ 
Assiut Vet. Med. J. Vol. 60 No. 141 April 2014

Table (8) shows the calculation of total cost, revenues and net profit for the experimental groups. The results obtained from the economic study indicated that, treatment (c) with 3\% garlic powder showed the highest profitability ratio (1.30) as compared to the control group.

Table 8: Total cost, revenues and net profit of broiler chicks fed on different levels of garlic powder.

\begin{tabular}{|c|c|c|c|c|}
\hline Item & $\mathrm{A}$ & $\mathrm{B}$ & $\mathrm{C}$ & $\mathrm{D}$ \\
\hline \multicolumn{5}{|l|}{ Cost (SDG) } \\
\hline Chick purchase & 6.0 & 6.0 & 6.0 & 6.0 \\
\hline Management & 4.0 & 4.0 & 4.0 & 4.0 \\
\hline Feed & 11.4 & 12.0 & 12.3 & 12.5 \\
\hline Total cost & 21.4 & 22.0 & 22.3 & 22.5 \\
\hline \multicolumn{5}{|l|}{ Revenues } \\
\hline Average eviscerated carcass weight $(\mathrm{kg})$ & 1.278 & 1.398 & 1.502 & 1.363 \\
\hline Price (SDG/kg) & 23 & 23 & 23 & 23 \\
\hline Total revenues & 29.39 & 32.15 & 34.55 & 31.36 \\
\hline \multicolumn{5}{|l|}{ Net profit } \\
\hline Total revenues & 29.39 & 32.15 & 34.55 & 31.36 \\
\hline Total cost & 21.40 & 22.00 & 22.30 & 22.50 \\
\hline Net profit/bird & 7.99 & 10.15 & 12.25 & 8.86 \\
\hline Net profit/kg meat & 6.25 & 7.26 & 8.15 & 6.51 \\
\hline Profitability ratio/kg meat & 1.00 & 1.16 & 1.30 & 1.04 \\
\hline
\end{tabular}

Total cost calculated according to 2014 a current (2014) price of meat 23 (SDG)/kg

\section{DISCUSSION}

The effect of feeding different levels of garlic powder on productive performance of broilers is shown in Table (4). Treatment effect on the final body weight, body weight gain, total feed intake and feed conversion ratio was significant $(\mathrm{P}<0.05)$. The inclusion of garlic powder in diet of broiler significantly $(\mathrm{P}<0.05)$ enhanced the body weight and the weight gain as compared to the control group. The improved weight gain of bird fed on garlic powder could be attributed to allicin active ingredients in garlic which promotes the performance of intestinal flora, thereby improving digestion and enhance the utilization of energy, which improve the growth of birds. This result was in line with the finding of ELGamry et al. (2002); Tollba and Hassan (2003); AlHomidan (2005) and Fayed et al. (2011) who found that the dietary garlic powder improved significantly the weight gain of broiler chicks. The birds fed on $3 \%$ level of garlic powder produced significantly $(\mathrm{P}<0.05)$ the highest body weight gain as compared to the other experimental groups. Similar results were obtained by Soliman (2000) who mentioned that addition of dried garlic to diet at level 3\% improved significantly the productive performance of broiler chicks. The results coincided with the finding of Ahmed (2005) who found higher weight gain of broiler chicks fed on ration supplemented with garlic as natural growth promoter. In addition to, Ziton (2009) stated that, the supplementation of basal diet with dried garlic at levels 2, 3 and 4\%, respectively had significantly better weight gain than the control group.

The feed intake significantly $(\mathrm{P}<0.05)$ tended to be higher in the birds that fed on garlic powder diets compared to the control group. The highest feed intake was significantly $(\mathrm{P}<0.05)$ produced by the birds fed on $3 \%$ level of garlic powder. These results 
are in agreement with those reported by Racesi et al. (2010) who indicated that, the diet supplemented with garlic powder at level 1-3\% had significantly better feed intake compared to the control diet.

The feed conversion ratio was affected significantly $(\mathrm{P}<0.05)$ by the experimental diets. There was a significant $(\mathrm{P}<0.05)$ improvement in the feed conversion ratio of the birds fed on diets which supplemented with garlic powder compared to the control diet. The best feed conversion ratio was significantly $(\mathrm{P}<0.05)$ obtained by the diet with $3 \%$ level of garlic powder. The better feed conversion ratio can be attributed to the anti-bacterial properties of the garlic powder which resulted in better absorption of the nutrients in the gut and finally leading to improvement in feed conversion ratio. These results are consistent with the finding of Soliman (2000); El-Gamry et al. (2002); Tollba and Hassan (2003) and Ziton (2009) who mentioned that, addition of garlic powder in broilers diet improved significantly the feed conversion ratio of the broilers. Treatment effect on mortality rate was not significant. Birds were kept in clean disinfected environment following all hygiene regulation programs, only one bird from each treatment was died, which cannot be related in any way to the experimental treatment. The results are in agreement with those reported by Fayed et al. (2011) who found that supplementation of garlic powder in broiler diets with $1 \mathrm{~kg} / \mathrm{ton}$ and $0.5 \mathrm{~kg} / \mathrm{ton}$ had no significant differences in mortality rate.

As shown in Table (5), the hot and cold dressing percentages were significantly $(\mathrm{P}<0.05)$ increased for birds fed on garlic powder based diets as compared to the control group. Birds fed on diet with $3 \%$ garlic powder produced significantly $(\mathrm{P}<0.05)$ the highest hot and cold dressing percentages, while birds fed on the control diet produced the lowest percentage values. These results are in line with the finding of Dieumou et al. (2012) who reported that, carcass dressing percentage of broiler chicks fed on diets supplemented with garlic essential oil were better significantly $(\mathrm{P}<0.05)$ than values obtained from those fed on the control diet. In contrast, Ziton (2009) reported that, addition of garlic powder in broilers diet had no significant effect on dressing percentage. The percentages of commercial cuts (breast, drumstick and thigh) showed significant $(\mathrm{P}<0.05)$ variation between the dietary treatment groups. The addition of garlic powder in broiler diets significantly $(\mathrm{P}<0.05)$ increased the breast percentage and decreased the thigh and drumstick percentages. The diet with $3 \%$ level garlic powder produced significantly $(\mathrm{P}<0.05)$ the highest breast percentage, while the highest drumstick and thigh percentages were produced by the group fed the control diet. Similar results were reported by Miller (1965) who indicating that, a decrease of breast percentage is counteracted by a corresponding increase in the other body proportions of broiler carcasses. As shown in Table (6), the inclusion of garlic powder in the broiler diets significantly $(\mathrm{P}<0.05)$ affected the percentages of giblets (abdominal fat, liver and gizzard) except the heart percentage. Generally, it seems that, the higher percentages of garlic in the diets, the lower percentages of the abdominal fat, liver and gizzard as compared to the control diet. The reduction in the percentage of abdominal fat for the diets that supplemented with garlic powder may be attributed to the action of garlic which have been reported to possess lipid lowering effects (Agarwal, 1996). Similar results were obtained by several studies which showed that, the addition of garlic and its essential oils to broiler diet as growth promoters reduced significantly the serum level of cholesterol and triglyceride (Pesti, 1997; Meraj, 1998; Ademola et al., 2009; Onibi et al., 2009 and Rahimi et al., 2011).

As shown in Table (7) no significant differences were observed between all treatment groups in subjective meat quality attributes (colour, flavour, juiciness and tenderness) of the breast and thigh meat. All score being at above moderate values. However, Eugeiuszr and Edyta (2007) inform that $5 \mathrm{mg} / \mathrm{kg}$ diet of dried garlic contributed to the increase sensory assessment of chicken meat as compared to control diet.

As shown in Table (8), the economical evaluation of the experimental diets indicated that, the diet with $3 \%$ level garlic powder showed the highest profitability ratio (1.3) as compared to the control group. This might be due to the highest return of the weight gains recorded by this group of chicks.

It could be concluded that the incorporation of garlic in broiler diet as feed additive at 3\% level significantly enhanced growth and productive performance of broiler chicks.

\section{REFERENCES}

Ademola, S.G.; Farinu, G.O. and Babatude, G.M. (2009): Serum lipid, growth and hematological parameters of broilers fed garlic, ginger and their mixtures. World J. Agric. Sci., 5: 99-104.

Agarwal, K.C. (1996): Therapeutic actions of garlic constituents. Med. Res., 16: 111-124.

Ahmad, S. (2005): Comparative efficiency of garlic, turmeric and kalongi as growth promoters in broiler. M.Sc. Thesis, Department of Poultry Science, University of Agriculture, Faisalabad, Pakistan.

Al-Homidan, A.A. (2005): Efficiency of using different sources and levels of Allium cepa, Allium sativum and Zingiber officinale on broiler chicks performance. Saudi Journal of Biological Science, 12 (2): 96-102. 
Amagase, H. and Milner, J.A. (1993): Impact of various sources of garlic and their constituents on 7, 12-dimethylbenz (a) anthracene binding to mammary cell DNA. Carcinogenesis, 14: 1627-1631.

Ankri, S. and Mirelman, D. (1999): Antimicrobial properties of allicin from garlic. Microbes infect. Feb., 1 (2): 125-129.

$A O A C$ (1995): Official methods of analytical $\left(12^{\text {th }}\right.$ ed). Association of Official Analytical Chemists, Washington, D.C., USA.

Bager, F. (1998): Consumption of antimicrobial agents and occurrence of antimicrobial resistance in bacteria from food animals. Food and human in Denmark, Dansk, Copenhagen, Zoonocenter, Denmark.

Cross, H.R; Moen, R. and Stanfield, M.S. (1978): Training and testing of judges for sensory analysis of meat quality. Food Technology, 32-48.

Demir, E.; Kiline, K. and Yildirim, Y. (2005): Use of antibiotic growth promoter and two herbal natural feed additives with and without exogenous enzymes in wheat base broiler diets. South Africa anim. Sci., 35: 61-72.

Dieumou, F.E.; Teguia, A.; Kuiate, J.R.; Tamokou, J.D.; Fonge, N.B. and Donogmo, M.C. (2009): Effect of ginger (Zingiber officinale) and garlic (Allium sativum) essential oils on growth performance and gut microbial population of broiler chicks. Livestock Research for Rural Development, 21 (8): 21-33.

Dieumou, F.E.; Teguia, A.; Kuiate, J.R.; Tamokou, J.D.; Doma, U.D.; Abdullahi, U.S. and Chiroma, A.E. (2012): Effect of diets fortified with garlic extract and streptomycin sulphate on growth performance and carcass characteristics of broilers. International Journal of Livestock and Production, 3 (4): 36-42.

Donoghue, D.J. (2003): Antibiotic residues in poultry tissues and eggs human health concerns. Poultry Science, 82 (4): 618-621.

El-Gamry, A.A.; El-Mallah, G.M. and Yamny, A.T. (2002): The effect of incorporation yeast culture, Nigella sativa and fresh garlic in broiler diets on their performance. Egyptian Poultry Science, 22: 445-459.

Ellis, N. (1981): The nutrient composition of Sudanese animal feeds. Bulletin, 1: Northern and Central Sudan, Central Animal Nutrition Research Laboratory, Kuku Research Centre, Khartoum North, Sudan.

Eugeiuszr, R. and Edyta, K. (2007): Herbs in animal feeding. Herba Polonica, 53(3): 360-365.

Fayed, R.H.; Razik, A.A. and Ouf, G. (2011): Effect of dietary garlic supplementation on performance, carcass traits and meat quality in broiler chicken. XVISAH Congress, Vienna.

Konjufca, V.H.; Pasti, G.M. and Bakalli, R.I. (1997): Modulation of cholesterol levels in broiler meat by dietary garlic and chopper. Poult. Sci., 76: $1264-1271$

Meraj, I.C.A. (1998): Effect of garlic and neem leaves supplementation on the performance of broiler chickens. M.Sc. Thesis, Department of Poultry Science, University of Agriculture, Faisalabad, Pakistan.

Miller, B.F. (1965): Edible yield of Turkey parts. Poult. Sci., 44: 848-853.

NRC, National Research Council (1994): Nutrient requirements of poultry $\left(9^{\text {th }}\right.$ Rev. ed $)$ National Academy Press, Washington, D.C., USA.

Onibi, G.E.; Oluwatoyin, E.; Adebisi, A.; Fajemisin, N.; Ayode, V. and Adetum, J.I. (2009): Response of broiler chickens in terms of performance and meat quality to garlic (Allium sativum) supplementation. African Journal of Agricultural Research, 4 (5): 511-517.

Pesti, G. (1997): Poultry meat with lower cholesterol. Poult. Inter, 31-36.

Racesi, M.; Hoseini-Aliabad, S.A.; Roofchaee, A.; Shahneh, A. and Pirali, S. (2010): Effect periodically use of garlic (Allium sativum) powder on performance and carcass characteristics in broiler chicken. World Academy of Science, Engineering and Technology, 68: 1213-1219.

Rahimi, S.; Zadeh, Z.; Torshizi, M.A.; Omidbagi, R. and Rokin, H. (2011): Effect of the three herbal extracts on growth performance, immune system, blood factors and intestinal selected bacterial population in broiler chickens. J. Agric. Sci. Tech., 13: 527-539.

Singh, M.P. and Panda, H. (2005): Medicinal herbs with their formulations. Volume 1- Allium sativum, Daya Publishing House, Delhi, 110035.

Soliman, N. (2000): Histological and histochemical studies on the effect of garlic (Allium sativum) extract on the liver and lung of albino rat. M.Sc. Thesis, Histology Dept., Fac. Med., Ain Shams University, Cairo, Egypt.

Steel, R.G.D. and Torrie, J.H. (1986): Principles and procedures of statistics: A Biometrical Approach ( $2^{\text {nd }}$ ed). McGraw Hill Book company, Inc., NY, USA.

Tollba, A.A. and Hassan, M.S. (2003): Using some natural additives to improve physiological and productive performance of broiler chicks under high temperature conditions. Black cumin (Nigella sativa) or garlic (Allium sativum). Poult. Sci., 23: 327-340.

Tsao, S.M. and Yin, M.C. (2001): In vitro activity of garlic oil and four diallyl-sulfides against antibiotic resistant Pseudomonas aeruginosa and Klebsiella pneumoniae. Antimicrob. Chemother, 47: 665-670.

Weber, N.D.; Anderson, D.O.; North, J.A.; Murray, B.K. and Lawson, L.D. (1992): In vitro 
virucidal effects Allium sativum (garlic) extract and components. Planta Med., 58: 417-423.

Wikipedia, the free encyclopedia (2013): Htt://en.wikipedia.org/wiki/Garlic.

Ziarlarimi, A.; Irani, M.; Gharahveysi, S. and Rahmani, Z. (2011): Investigation of antibacterial effect of garlic (Allium sativum), mint (Menthe spp.) and onion (Allium cepa) herbal extracts on Escherichia coli isolated from broiler chickens. African Journal of Biotechnology, Vol. 10 (50), pp. 10320-10322.

Ziton, A.A. (2009): Response of broiler chicks to diet containing garlic as natural feed additive. M.Sc. Thesis, College of Agricultural Studies and Technology.

\section{أثر استخدام مسحوق الثوم كاضافة علقية طبيعية على الأداء وخصائص الأبيح فى الاجاج اللاحم صفاء محمد عبد الوهاب التازى ، كمال عبد الباقى محمد الكنانس ، مختار أحد مختار E-Mail:safamohamedeltazi@yahoo.com.}

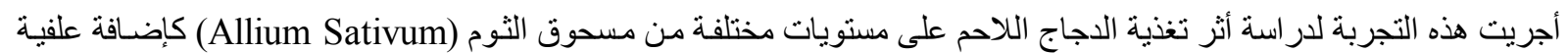

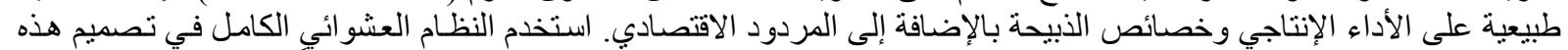

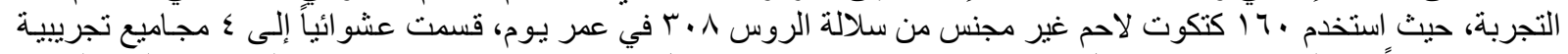

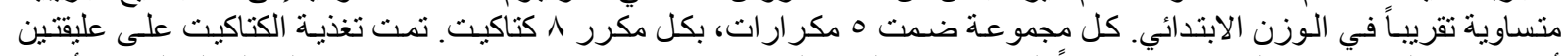

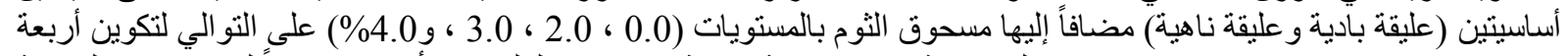

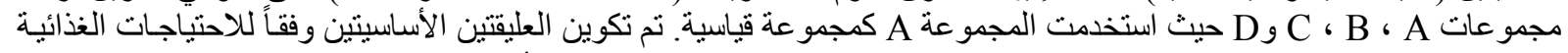

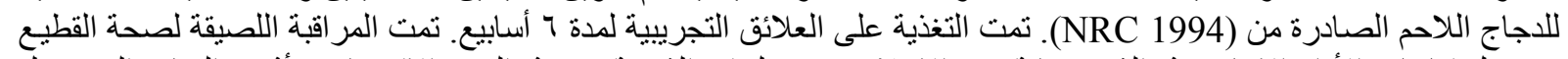

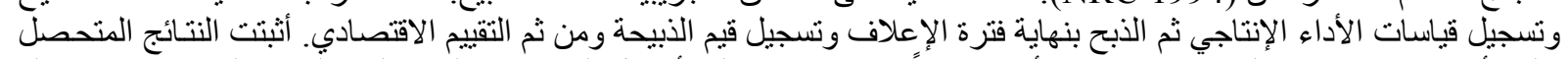

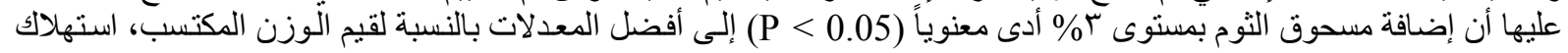

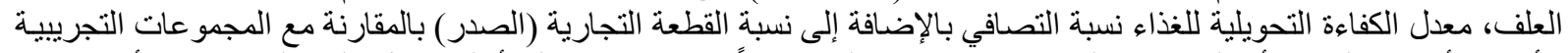

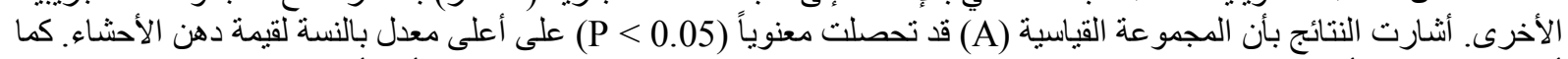

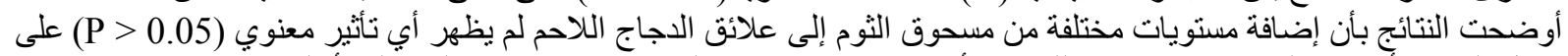

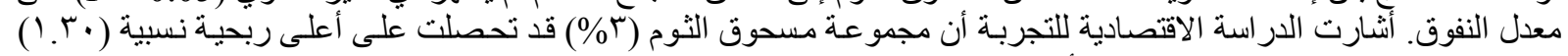
بالمقارنة مع بقية المجمو عات التجريبية الأخرى. 